\title{
Electrochemical remediation of industrial pharmaceutical wastewater containing hormones in a pilot scale treatment system
}

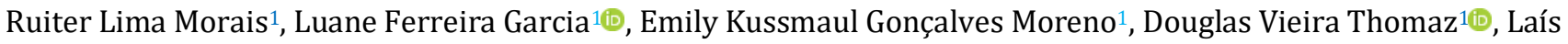 \\ de Brito Rodrigues ${ }^{1}$, Lara Barroso Brito ${ }^{1}$, Germán Sanz Lobón ${ }^{2}$, Gisele Augusto Rodrigues de Oliveira1®i , Marcella \\ Ferreira Rodrigues ${ }^{2}$, Boniek Gontijo Vaz ${ }^{2}$ (D) Eric de Souza Gil ${ }^{1+(i)}$
}

1 Federal University of Goiás, Faculty of Pharmacy, Goiânia, Goiás, Brazil

2 Federal University of Goiás, Institute of Chemistry, Goiânia, Goiás, Brazil

+ Corresponding author: Eric de Souza Gil, phone: +55 62 3202-1278, e-mail address: ericsgil@gmail.com

\section{ARTICLE INFO}

Article history:

Received: September 25, 2018

Accepted: November 26, 2018

Published: January 28, 2019
Keywords:

1. algestone acetophenide

2. estradiol enanthate

3. electrocoagulation remediation

4. ecotoxicity

5. mass spectrometry

\begin{abstract}
The elimination of residual drugs from pharmaceutical and domestic sources is a growing concern, as they are able to reach water and soil resources and can present environmental and health risks even in very low concentrations. Traditional water and wastewater treatment systems have not been efficient in the removal of these compounds, evidencing the importance of the development of new remediation methods. In view of the applicability and versatility of electrocoagulation techniques in the removal of pollutants, the aim of this work is to evaluate the parameters: biochemical oxygen demand (BOD), chemical oxygen demand (COD), color, turbidity, algestone acetophenide (AAc) and estradiol enanthate (EEn) using a pilot treatment system, as well as phytotoxicity and Brine shrimp toxicity. The study showed good removal efficiency, comprising remarkable remediation performance assayed through BOD (61.5\%), COD (58.6\%), color (83.1\%), turbidity (96.7\%), AAc (77.0\%) and EEn (56.7\%) after 30 minutes. For toxicity, raw effluent was considered more phytotoxic for lettuce and cucumber seeds when compared to treated effluent. The results suggest that the pilot prototype was promising, providing an increase in both the germination potential and the root growth of the seeds (Lactuca sativa and Cucumis sativus) and a significant decrease in the acute toxicity to Artemia salina.
\end{abstract}

\section{Introduction}

The residual drugs disposal from pharmaceutical and domestic sources is encompassed among the anthropogenic actions of greater environmental impact ${ }^{1}$. Hence inefficient wastewater treatment, emerging pollutants such as drugs and their metabolites are able to reach water bodies and soil, therefore leading to environmental and health hazards ${ }^{2}$.

Residual drugs are usually found in the environment at concentrations of $\mu \mathrm{g} \mathrm{L}^{-1}$ (ppb) or ng
$\mathrm{L}^{-1}(\mathrm{ppt})^{3}$, this chronic exposure to subtoxic doses of the drug may result in a number of undesirable effects on both the human organism and the environment ${ }^{4}$. Studies demonstrate the relationship between residual drugs and health problems, which vary upon the class, mental disorders, sexual dysfunctions $^{5}$ (Santos et al. and resistance to antibiotics $^{6}$ are some illustrative examples).

In this context, owing to the widespread occurrence, synthetic hormones are considered major threats. Moreover, such compounds present high stability, being invulnerable to common 
remediation methods, leading to their omnipresence in pharmaceutical wastewaters ${ }^{7,8}$.

The synthetic hormones AAc and EEn are worldwide consumed drugs used as contraceptive and anti-inflammatory agents ${ }^{9}$. Once these steroids are metabolized in the body, their metabolites are excreted through the urine/feces and dumped in Wastewater Treatment Plants (WWTP) ${ }^{10}$ Though steroids like AAc and EEn have been mostly omitted by environmental legislation, they represent a real risk to the environment and human healthy ${ }^{11}$. Therefore, great effort has been done in order to improve the efficiency of current remediation processes ${ }^{12}$.

The presence of steroids and their metabolites in aquatic and terrestrial environments can be explained by their non-biodegradable nature, recalcitrance, and by continuous release in environment, which is nonetheless much superior than their removal, henceforth characterizing them as "pseudo-persisted". Thus, conventional biological and chemical treatments become ineffective ${ }^{13,14}$. Another limiting factor of biodegradation is related to the interconversions between steroids caused by some microorganisms ${ }^{15}$.

The use of different advanced oxidation processes (AOP) involving Fenton, photocatalysis, $\mathrm{UV}-\mathrm{H}_{2} \mathrm{O}_{2}$, ozone, ozone-UV, plasma-based processes and sonolysis as promising technologies to deal with some environmental problems has been intensely investigated worldwide by numerous researchers ${ }^{16,17}$. Even though AOPs appear to be promising and attractive options, handicaps like as high costs (energy, inputs), sustainability (resource use, carbon footprint), byproduct formation and experimental level still prevent them from being widely used ${ }^{18,19}$. Therefore, the use of renewable energy sources to supply processes, the development of less expensive hardware and electrodes and more versatile systems are needed to diffuse and launch the industrial application of these technologies ${ }^{20,21}$.

Hence biodegradation and AOPs limitations to promote steroids removal in waterbodies effluents, methods such as electroremediation by electrocoagulation (EC) are becoming increasingly used due to their wide applicability, low cost and high efficiency. Electrocoagulation is constituted by three main steps: (1) oxidation/reduction reactions at electrode surface, (2) generation of coagulating agents from aluminum or iron (steel) electrodes immersed in the aqueous solution, (3) adsorption of soluble or colloidal pollutant particles on coagulants, and removal by sedimentation and/or flotation. These processes can efficiently mop up pollutants, which would be otherwise unable to undergo degradation through biological remediation methods ${ }^{22,23}$.

Owing to electrocoagulation techniques applicability in treatment of industrial wastewater, the aim of this work is to assess the improvement of BOD, COD, color and turbidity parameters of treated pharmaceutical wastewater, as well as the removal of synthetic hormones AAc and EEn using a pilot electrocoagulation treatment system. In order to evaluate the effluents toxicity, tests concerning phytotoxicity and acute toxicity with Artemia salina were henceforth performed.

\section{Materials and methods}

\subsection{Pilot Scale Treatment System (PSTS)}

The pilot scale prototype consisted in square aquarium, made in acrylic material, presenting the following dimensions: $38 \mathrm{~cm}$ long, $24 \mathrm{~cm}$ wide and $30 \mathrm{~cm}$ high, in which 16 stain steel 1020 electrodes $\left(20 \times 27 \times 6.35 \mathrm{~cm}\right.$ each) with $1,728 \mathrm{~cm}^{2}$ of total surface were equally distributed (Figure 1).

The raw effluent sample used was collected in pharmaceutical industry, dedicated to the production of hormonal drugs in Goiânia-Brazil, and the initial treatment conditions were: electric current 14.9-15.4 A (Direct Current - DC); applied potential of 26.5-26.8 V. The inversion of polarity between cathode and anode was performed every 20 minutes. Temperature and electrical parameters were monitored during the treatment regimen/experiment at 10, 20 and 30 minutes. The temperature shifts were monitored in an Infrared Temperature Tester Thermometer GM300 (Benetech, Shenzhen Jumaoyuan Science And Technology Co., Ltd, Shenzhen, China), whereas the current and potential with a Digital Clamp AC/DC Voltmeter F203 (Chauvin Arnoux Metrix, France). 


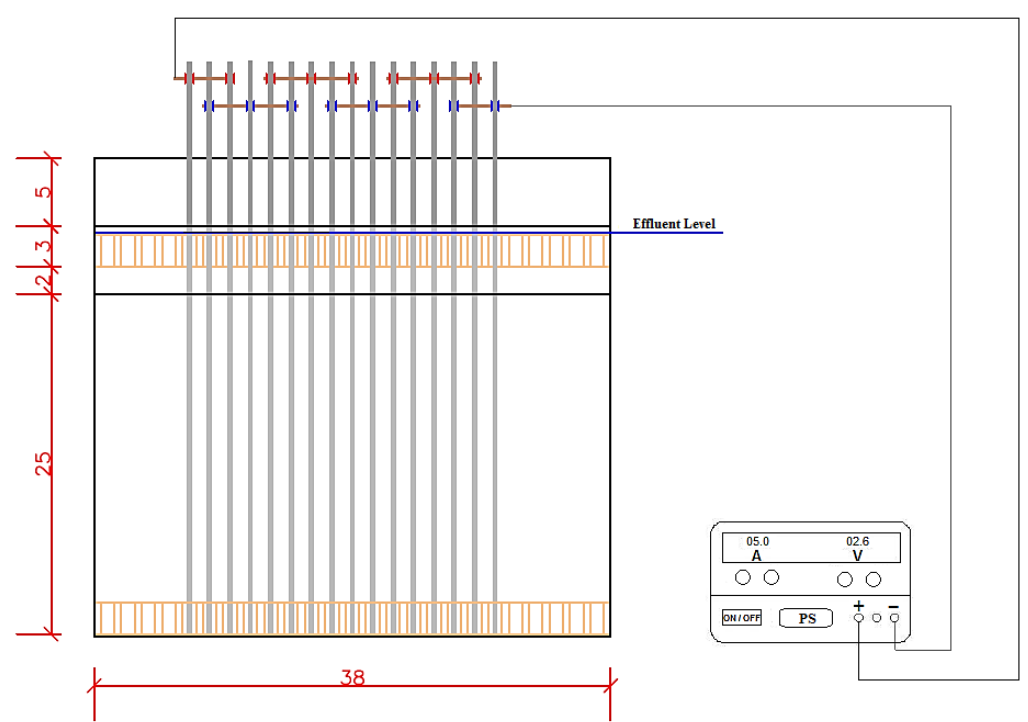

Figure 1. Pilot scale treatment system.

Electrical conductivity, color, $\mathrm{BOD}, \mathrm{COD}, \mathrm{pH}$, and turbidity were monitored in this study since they are good indicators of wastewater quality. The tests were performed according to the techniques recommended by the Standard Methods for the examination of Water and Wastewater ${ }^{24}$.

Some characteristics of synthetic hormones studied are summarized in Table 1.

Table 1. Some characteristics of the synthetic hormones studied.

\begin{tabular}{|c|c|c|}
\hline & Acetophenide Algestone $^{25}$ & Estradiol Enanthate $^{26}$ \\
\hline Structure & & \\
\hline $\begin{array}{c}\text { Solubility }\left(\mathrm{mg} \mathrm{L}^{-1}\right) \\
\text { (Estimated by Log } \\
\left.\mathrm{K}_{\text {ow }}\right)\end{array}$ & 0.02864 & 0.006894 \\
\hline $\log K_{o w}$ & 5.53 & 7.40 \\
\hline
\end{tabular}

The experiment was performed in triplicate (T1, $\mathrm{T} 2$ and T3) from the same industrial effluent sample and no additions of chemical compounds were made for correction purposes.

\subsection{Mass Spectrometry Analysis}

Mass spectrometry (MS) analysis was carried out in a mass spectrometer microTOF III (Brucker Daltonics, Bremen, Germany) equipped with a commercial ESI source (Brucker Daltonics, Bremen, Germany). Samples were methanoldiluted to a (1:1000) ratio, followed by acidification with $0.1 \%$ formic acid. The resulting solution was directly injected with a flow rate of 4 $\mu \mathrm{L} \min ^{-1}$, all analyses were performed in the positive full scan mode (m/z 100-1000). ESI(+) source conditions were as follows: nebulizer nitrogen gas temperature and pressure of 2.0 bar and $200{ }^{\circ} \mathrm{C}$, capillary voltage of $-4 \mathrm{kV}$, transfer capillary temperature of $200{ }^{\circ} \mathrm{C}$; drying gas of $4 \mathrm{~L}$ $\mathrm{min}^{-1}$; end plate offset of $-500 \mathrm{~V}$; skimmer of $35 \mathrm{~V}$ and collision voltage of $-1.5 \mathrm{~V}$. Each spectrum was acquired using 2 microscans per second for one minute. The resolving power $(\mathrm{m} / \Delta \mathrm{m} 50 \%$ $16.500,00$, where $\Delta \mathrm{m} 50 \%$ is the peak full width at half-maximum peak height). Mass spectra were acquired and processed with Data Analysis software (Brucker Daltonics, Bremen, Germany).

A quantification method by MS was also designed focusing the assessment of pilot scale treatment system efficiency. To avoid matrix effect, calibration curves for AAc using gestodene as secondary standard were constructed. The 
quantification was possible through calculation of the relation between gestodene and AAc, therefore measuring the intensity in several defined concentration for wastewater and treated water.

To develop calibration curves, $1 \mathrm{mg} \mathrm{mL}^{-1}$ AAc and gestodene stocks solutions in methanol were prepared and subsequently diluted to concentrations: $0.5 ; 2.0 ; 3.5 ; 5.0 ; 6.5 \mathrm{mg} \mathrm{L}^{-1}$. In 500 $\mu \mathrm{L}$ of water sample was added the appropriate volume of the stock solution and finally was added the $0.1 \%$ formic acid to helped in ionization process.

Chemicals used were all of ACS grade, and purchased from Sigma-Aldrich, they were used without any further purification. MS and High Performance Liquid Chromatography (HPLC) grade solvents were purchased from J.T. Baker.

\subsection{Ecotoxicity Tests}

The ecotoxicity tests were performed only on the sample that presented the best result of removal of estrogenic compounds.

\subsubsection{Phytotoxicity Tests}

Lettuce (Lactuca sativa) and cucumber (Cucumis sativus) seeds were purchased from an agriculture local supplier. The seed germination and root elongation test on filter paper was performed according to the US Environmental Protection Agency ${ }^{27}$ seed germination/root elongation toxicity test. Before the test, the seeds were sterilized with $0.1 \%$ sodium hypochlorite solution for $10 \mathrm{~min}$ and then rinsed several times in distilled water to prevent fungal growth. Ten seeds of each species were exposed on filter paper (Whatman 2) containing $2.5 \mathrm{~mL}$ of raw or treated effluents at $6.25,12.5,25,50$ and $100 \%(\mathrm{v} / \mathrm{v})$ and placed in a Petri dish. Distilled water was used as negative control and zinc sulfate heptahydrate $\left(\mathrm{ZnSO}_{4} .7 \mathrm{H}_{2} \mathrm{O} ; 10 \mathrm{mg} \mathrm{mL}^{-1}\right)$ as positive control. Three plates per concentration were prepared and incubated in complete darkness in a growth chamber at $25 \pm 1^{\circ} \mathrm{C}$ for $120 \mathrm{~h}$.

After this exposure time, the number of germinated seeds was counted, and the length of the root measured. Tests were only considered valid if $80 \%$ of control seeds had germinated and the roots size was at least $5 \mathrm{~cm}$ long. The percentage of relative seed germination was calculated by dividing the number of seeds germinated in the exposed groups by the number of seeds geminated in the negative control. The percentage of relative root elongation was calculated by dividing the mean root length in raw or treated effluents exposures by the mean root length in the negative control.

\subsubsection{Brine shrimp toxicity assay}

The brine shrimp bioassay was performed based on the Meyer ${ }^{28}$ method and OECD Guideline $202^{29}$ with modifications. Brine shrimp (Artemia salina) nauplii were obtained by hatching dehydrated cysts in artificially prepared seawater (3.5\% commercial marine salt [Blue Treasure ${ }^{\circledR}$ ] in deionized water) at $27 \pm 1{ }^{\circ} \mathrm{C}$, under continuous light and aeration for $48 \mathrm{~h}$. For the test, 20 nauplii divided into 4 groups of 5 organisms each, were exposed to $2 \mathrm{~mL}$ of raw and treated effluents at $6.25 ; 12.5 ; 25 ; 50$ and $100 \%$ $(\mathrm{v} / \mathrm{v})$. All test solutions were prepared in artificial seawater. Microplates were incubated in the dark in a climatic chamber for $48 \mathrm{~h}$ at $27 \pm 1{ }^{\circ} \mathrm{C}$. Artificial seawater was used as the negative control and $10 \mathrm{mg} \mathrm{L}^{-1}$ dodecyl sulfate sodium salt (SDS) as the positive control.

After 24 and $48 \mathrm{~h}$, the number of dead nauplii (immobility) in control and exposed groups was counted. The percentage of immobility induced by the effluents was compared with that of the control group. The test was considered valid if the immobilization rate was less than $10 \%$ in the negative control group ${ }^{29}$.

\subsubsection{Statistical analysis}

Ecotoxicity tests were evaluated using ANOVA and Dunnett's post hoc test using the GraphPad Prism program. Each experimental value was compared with its corresponding control. Statistical significance was accepted at $\mathrm{p}<0.05$. Toxicity was expressed as effective $\left(\mathrm{EC}_{50}\right)$ and lethal $\left(\mathrm{LC}_{50}\right)$ concentrations with their $95 \%$ confidence limits.

\section{Results and discussion}

\subsection{Physicochemical Data and Removal Efficiency}

The electrics conditions in treatment system are showed on Table 2. 
Table 2. Electrical conditions during the tests with the pilot system.

\begin{tabular}{|c|c|c|c|c|c|c|c|c|c|c|c|c|c|c|c|}
\hline \multirow{2}{*}{$\begin{array}{l}\text { Time } \\
\text { (min) }\end{array}$} & \multicolumn{5}{|c|}{ Temperature $\left({ }^{\circ} \mathbf{C}\right)$} & \multicolumn{5}{|c|}{ Voltage (V) } & \multicolumn{5}{|c|}{ Current (A) } \\
\hline & T1 & T2 & T3 & AV & SD & T1 & $\mathbf{T} 2$ & T3 & $\mathbf{A V}$ & SD & $\mathbf{T 1}$ & T2 & T3 & AV & SD \\
\hline 0 & 28.0 & & 28.2 & 28.0 & 0.2 & 26.8 & 26.5 & & & 0.2 & 15.4 & & & & 0.3 \\
\hline 10 & & & & & & & & & & & & 24.0 & & & 1.0 \\
\hline 20 & & 30.0 & 30.6 & 30.5 & & 26.5 & 26.1 & & & & 7 & 6.3 & 6 & & 0.4 \\
\hline 30 & 32.0 & 31.0 & 31.8 & 31.6 & 0.5 & 30.0 & 28.9 & 29.8 & 29.6 & 0.6 & 13.0 & 12.0 & 12.7 & 12.6 & 0.5 \\
\hline
\end{tabular}

$\mathrm{T} 1=$ Test $\mathrm{n}^{\circ} 1 ; \mathrm{T} 2=$ Test $^{\circ} 2 ; \mathrm{T} 3=$ Test $^{\circ} 3, \mathrm{AV}=$ Average$; \mathrm{SD}=$ Standard Deviation.

In the EC with inversion of polarity, the electrode that behaves as a cathode for a certain time, will behave like anode after the inversion of polarity, in this case, at 20 minutes. This inversion decreases the passivation, increasing electrode lifespan by up to three times, at the same time, reducing the resistivity of the system, thus, the cathode starts to release more $\mathrm{OH}^{-}$species in the solution, increasing the $\mathrm{pH}$ and the pollutant removal efficiency ${ }^{30}$.

Despite being under the same initial conditions a small variation of voltage and current (DC) was observed between the tests (T1, T2 and T3) probably due to electrode degradation between one test and another and/or small variations in the composition of the stock effluent.

A variation in voltage and current was also observed during each test. This has occurred due to a variation on the composition of effluent during the assays, as shown at Table 3. Also, these parameters were monitored to assess the electrochemistry removal process.

Table 3. Physicochemical parameters evaluated during the pilot tests.

\begin{tabular}{|c|c|c|c|c|c|c|c|}
\hline $\begin{array}{l}\text { Time } \\
(\text { min) }\end{array}$ & $\begin{array}{c}\text { Test } \\
\mathbf{n}^{\mathbf{0}}\end{array}$ & $\begin{array}{c}\text { Electrical } \\
\text { Conductivity } \\
\left(\mu \mathrm{S} \mathrm{cm}^{-1}\right)\end{array}$ & $\begin{array}{c}\text { Color } \\
\left(\mathrm{mg} \mathrm{L}^{-1}\right. \\
\left.\mathrm{CaCO}_{3}\right)\end{array}$ & $\begin{array}{l}\text { BOD } \\
\left(\mathbf{m g ~ L}^{-1}\right. \\
\left.\mathbf{O}_{2}\right)\end{array}$ & $\begin{array}{l}\text { COD } \\
\left(\mathrm{mg} \mathrm{L}^{-1}\right. \\
\left.\mathrm{O}_{2}\right)\end{array}$ & pH & $\begin{array}{c}\text { Turbidity } \\
\text { (NTU) }\end{array}$ \\
\hline \multirow{5}{*}{0} & $\mathrm{~T} 1$ & & & & & & \\
\hline & $\mathrm{T} 2$ & 3170.0 & 2550.0 & 14342.0 & 35360.0 & 5.4 & 385.0 \\
\hline & $\mathrm{T} 3$ & & & & & & \\
\hline & AV & 3170.0 & 2550.0 & 14342.0 & 35360.0 & 5.4 & 385.0 \\
\hline & SD & 0 & 0 & $\mathbf{0}$ & 0 & $\mathbf{0}$ & $\mathbf{0}$ \\
\hline \multirow{5}{*}{10} & $\mathrm{~T} 1$ & 3431.0 & 5700.0 & 8670.0 & 22320.0 & 10.8 & 520.0 \\
\hline & $\mathrm{T} 2$ & 3216.0 & 5900.0 & 9120.0 & 23055.0 & 10.2 & 550.0 \\
\hline & $\mathrm{T} 3$ & 3330.0 & 5800.0 & 8950.0 & 22679.0 & 10.6 & 530.0 \\
\hline & $\mathbf{A V}$ & 3325.7 & 5800.0 & 8913.3 & 22684.7 & 10.5 & 533.3 \\
\hline & SD & 107.6 & 100.0 & 227.2 & 367.5 & 0.3 & 15.3 \\
\hline \multirow{5}{*}{20} & $\mathrm{~T} 1$ & 3713.0 & 650.0 & 8790.0 & 22350.0 & 11.8 & 19.5 \\
\hline & $\mathrm{T} 2$ & 3564.0 & 690.0 & 9240.0 & 23205.0 & 11.5 & 32.0 \\
\hline & $\mathrm{T} 3$ & 3689.0 & 670.0 & 8910.0 & 22780.0 & 11.7 & 27.0 \\
\hline & $\mathbf{A V}$ & 3655.3 & 670.0 & 8980.0 & 22778.3 & 11.7 & 26.2 \\
\hline & SD & 80.0 & 20.0 & 233.0 & 427.5 & 0.2 & 6.3 \\
\hline \multirow{5}{*}{30} & $\mathrm{~T} 1$ & 4393.0 & 430.0 & 5525.0 & 14650.0 & 11.9 & 12.6 \\
\hline & $\mathrm{T} 2$ & 4139.0 & 490.0 & 5930.0 & 15120.0 & 11.6 & 25.0 \\
\hline & $\mathrm{T} 3$ & 4216.0 & 450.0 & 5660.0 & 14840.0 & 11.8 & 19.0 \\
\hline & $\mathbf{A V}$ & 4249.3 & 456.7 & 5705.0 & 14870.0 & 11.8 & 18.9 \\
\hline & SD & 130.2 & 30.6 & 206.2 & 236.4 & 0.2 & 6.2 \\
\hline \multicolumn{2}{|c|}{$\begin{array}{l}\text { Avarege Removal } \\
\text { Eff. }(\%)\end{array}$} & - & 82.1 & 60.2 & 57.9 & - & 95.1 \\
\hline
\end{tabular}

$\mathbf{T 1}=$ Test n $^{\circ} 1 ; \mathbf{T} 2=$ Test n$^{\circ} 2 ; \mathbf{T 3}=$ Test n $^{\circ} 3 ; \mathbf{A V}=$ Average; $\mathbf{S D}=$ Standard Deviation . 
A significant decrease of BOD (61.5\%), COD $(58.6 \%)$, turbidity $(96.7 \%)$ and color $(83.1 \%)$ after 30 minutes was noticed for the best result (T1). On the other hand, it was possible to observe the increase in electrical conductivity, $\mathrm{pH}$ and sludge production. The generation of sludge occurred due to the use of iron anodes and its consequent generation of iron hydroxides, thus playing the same role of flocculation in conventional coagulation treatment systems ${ }^{22}$.

When the steel anode is used $\mathrm{Fe}^{2+}$ is dissolved in the effluent from the anodic oxidation of $\mathrm{Fe}$, while $\mathrm{H}_{2}$ gas is generated in the cathode from the reduction of protons in acid medium and/or reduction of water in alkaline medium. Insoluble $\mathrm{Fe}(\mathrm{OH})_{2}$ precipitates at $\mathrm{pH}>5.5$ remaining in equilibrium with $\mathrm{Fe}^{2+}$ to $\mathrm{pH} 9.5$ or with monomeric species such as $\mathrm{Fe}(\mathrm{OH})^{+}, \mathrm{Fe}(\mathrm{OH})_{2}$ and $\mathrm{Fe}(\mathrm{OH})_{3}{ }^{-}$at high $\mathrm{pH}$ values. In the presence of $\mathrm{O}_{2}$ the dissolved $\mathrm{Fe}^{2+}$ is oxidized to insoluble $\mathrm{Fe}(\mathrm{OH})_{3}$ coagulating at $\mathrm{pH}>1.0$. The insoluble flakes can be in equilibrium with soluble monomeric species such as $\mathrm{Fe}^{3+}, \mathrm{Fe}(\mathrm{OH})^{2+}, \quad \mathrm{Fe}(\mathrm{OH})_{2}{ }^{+}, \mathrm{Fe}(\mathrm{OH})_{3}$ and $\mathrm{Fe}(\mathrm{OH})_{4}^{-}$as a function of $\mathrm{pH}$. These species act as coagulants or destabilizing agents that neutralize charges and separate colloids and ionic products from the wastewater by sedimentation or electroflotation, henceforth producing sludge (Figure 2) ${ }^{22}$.

The volume of sludge generated in the EC is reduced compared to conventional chemical coagulation or biological processes. However, hence the importance of pollutants removal, the sludge must be treated and discarded appropriately.

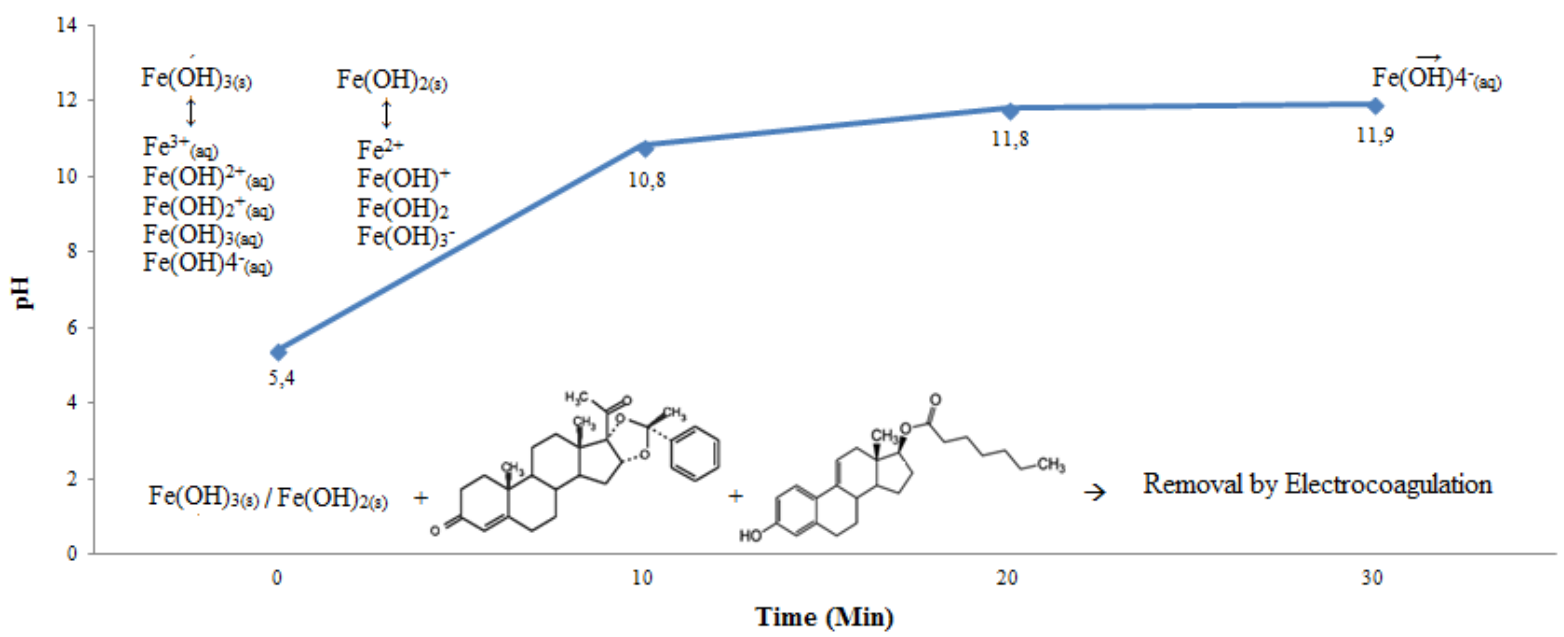

Figure 2. The behavior of $\mathrm{pH}$ and possible species formed during the EC of Test 1.

The $\mathrm{pH}$ effect of the effluent on the performance of the electrocoagulation process was evaluated throughout the experiments. The initial $\mathrm{pH}$ of 5.4 reached 10.8 after 10 minutes with the best removal efficiency of BOD (39.5\%) and BOD (36.9\%) in this range.

The initial $\mathrm{pH}$ of 5.4 may have facilitated the conversion of ferrous ions into ferric ions already in the early stages of electrolysis since this conversion occurs at $\mathrm{pH}>4$. Ferric ions $\left(\mathrm{Fe}^{3+}\right)$ undergo hydrolysis reactions and generate insoluble ferric hydroxides (microflocs) which are suspended by removing the contaminants by coagulation. When the $\mathrm{pH}$ reaches higher values $(\mathrm{pH}>11)$ the concentration of ferric complexes like $\mathrm{Fe}(\mathrm{OH})_{4}{ }^{-}$increases. This complex can remove contaminants through charge neutralization and adsorption, i.e., these precipitates can remove only contaminants from the water, which are positively charged $^{31}$. This fact explains the increase in the efficiency of BOD and COD removal with $\mathrm{pH}>$ 11.8.

From a physicochemical point of view, these results suggest that the pilot prototype was promising. This fact was supported by HPLC-MS analyzes of algestone acetophenide and estradiol enanthate, where the best removal rate was $77.0 \%$ and $56.7 \%$ respectively in the Test 1 (Table 4 and Figure 3). 
Table 4. Data regarding the removal of Algestone Acetophenide and Estradiol Enanthate taken from HPLC-MS.

\begin{tabular}{|c|c|c|}
\hline \multirow[b]{2}{*}{ Test } & \multicolumn{2}{|c|}{ Removal Efficiency (\%) } \\
\hline & $\begin{array}{c}\text { Algestone } \\
\text { Acetophenide }\end{array}$ & $\begin{array}{c}\text { Estradiol } \\
\text { Enanthate }\end{array}$ \\
\hline T1 & 77.0 & 56.7 \\
\hline $\mathrm{T} 2$ & 76.1 & 53.2 \\
\hline $\mathrm{T} 3$ & 76.7 & 55.2 \\
\hline AV & 76.6 & 55.0 \\
\hline SD & 0.46 & 1.76 \\
\hline
\end{tabular}
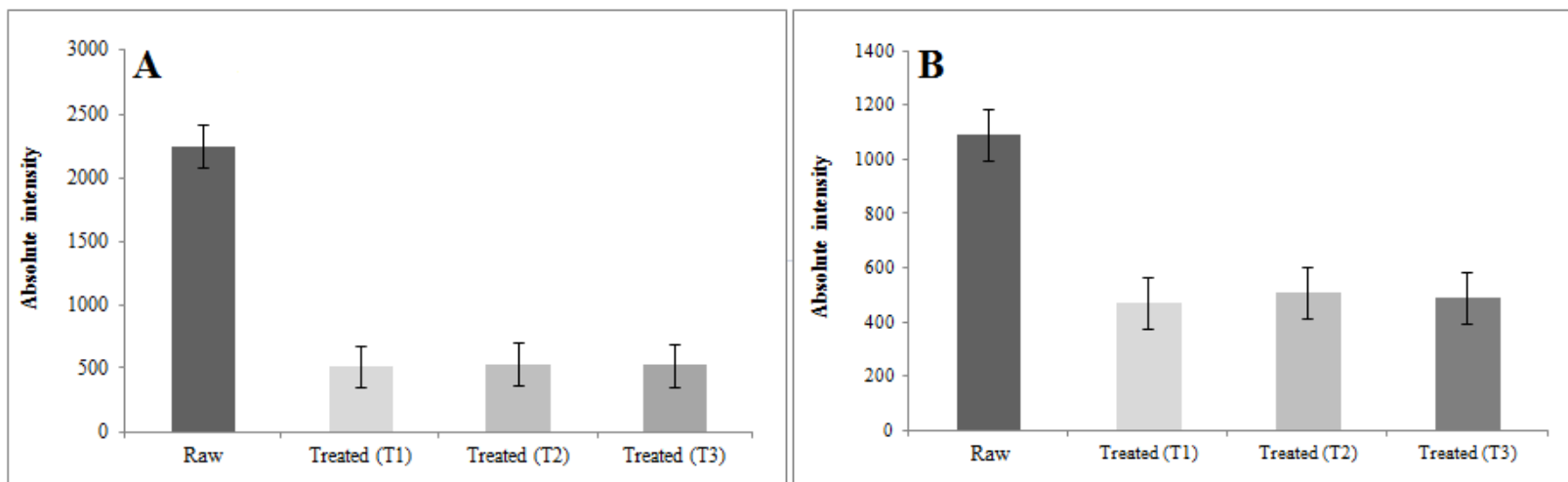

Figure 3. Removal rate of Algestone Acetophenide $-471.2441 \mathrm{~m} / \mathrm{z}$ (A) and Estradiol Enanthate $-433.2645 \mathrm{~m} / \mathrm{z}$ (B)

These results can be corroborating the quantification method by MS. The initial and final concentrations of AAc and EEn were calculated, $4.58 \mathrm{ppm}\left(\mathrm{y}=0.0758 \mathrm{x}+0.3487 ; \mathrm{r}^{2}>0.93\right)$ in wastewater and $0.98 \mathrm{ppm}\left(\mathrm{y}=0.064 \mathrm{x}+0.0063 ; \mathrm{r}^{2}\right.$ $>0.97)$.
The results found in the literature for treatment by electrocoagulation of estrogens are shown in Table 5.

Table 5. EC studies for hormones removal (best conditions).

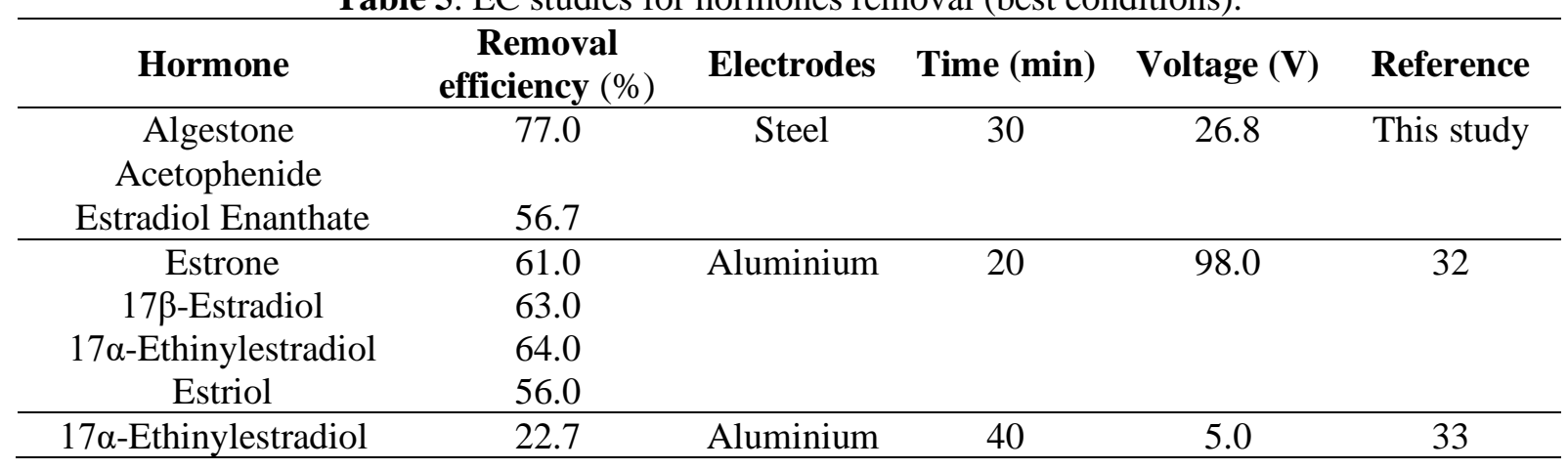

Understanding the physicochemical properties of steroidal compounds is crucial to predicting their fate in the aquatic or terrestrial environment. The distribution of organic pollutants between water and natural solids is often considered as a process of partitioning between the aqueous and organic phases. The water partition coefficient $\left(\mathrm{K}_{\mathrm{ow}}\right)$ is the ratio between the concentration of a compound in n-octanol and the water under equilibrium conditions at a given temperature. Compounds with high molecular weight and $\log \mathrm{K}_{\mathrm{ow}}>5$, such as AAc and EEn (Table 1), are easily adsorbed to sediments and can be removed mainly by coagulation $^{34}$. 
Every treatment system can generate toxic byproducts and monitoring both the primary compound and its degradation products is a complex and often unfeasible task. The use of toxicological assays can be considered a simple and efficient way to monitor these contaminants ${ }^{35,36}$. In this sense, toxicity tests were performed in the sample that presented the best compounds removal result (T1).

\subsection{Phytotoxicity}

Short-term toxicological tests are useful tools for predicting ecotoxicological risks, estimating acute toxicity, and establishing maximum acceptable concentrations of chemicals and byproducts released into the environment ${ }^{37,38}$. In the ecotoxicological assessment, phytotoxicity tests play an important role because plants are the basis of terrestrial and aquatic ecosystems, also acting as primary producers in the food chain ${ }^{39,40}$. Seed germination and root elongation test being the

(A)

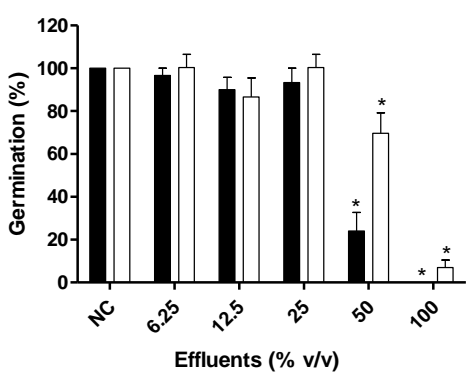

(C)

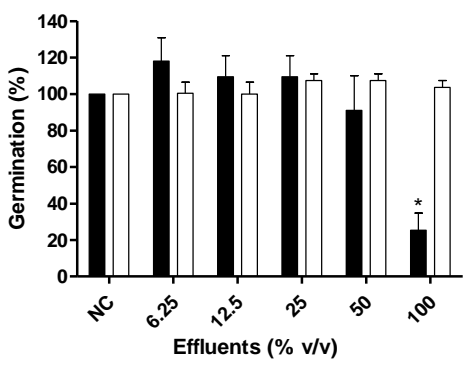

simplest one, however is sensitive and representative of the action of the toxicant at the first interface of the developing plant (seed) and its environment ${ }^{40-42}$. However, there is a lack of data on the effects of effluents generated by the pharmaceutical industry on seed germination and root elongation.

The effects of raw and treated effluents on seed germination and root length are presented in Figure 4. Both effluents induced significant effects on seed germination (Fig. 4A) and root elongation of L. sativa (Fig. 4B). Raw effluent inhibited the development of all species tested in a concentration-dependent manner (Fig. 4B and 4D). Only raw effluent at $100 \%$ (v/v) significantly reduced the seed germination rate of $C$. sativus and considering treated effluent had no significant effect on C. sativus germination (Fig. 4C). Treated effluent was less toxic for root length when compared to raw effluent, with effect significantly only at $100 \%$ (v/v) (Fig. 4D).

(B)

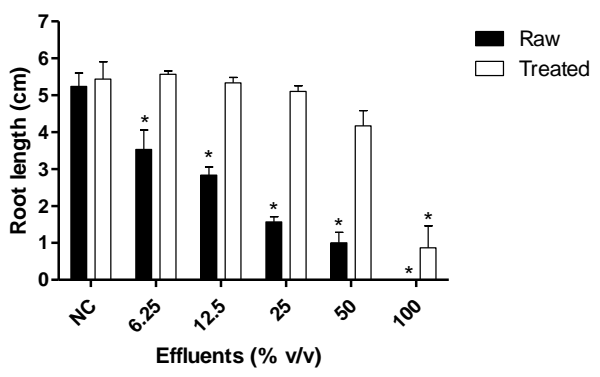

(D)

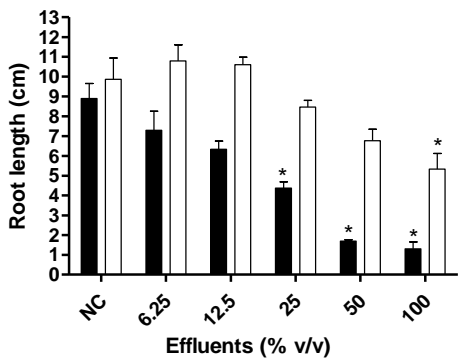

Figure 4. Seed germination and root length of Lactuca sativa (A and B) and Cucumis sativus (C and D) exposed to different concentrations of raw and treated effluents. Error bars represent \pm standard deviation of 3 replicates. Asterisk $(*)$ represents statistical difference $(\mathrm{p}<0.05)$ from the respective negative control (NC).

The potential toxicity of raw and treated effluents was expressed as the $\mathrm{EC}_{50}$ value (Table 6). For both species tested, raw effluent was more toxic than treated effluent with lower $\mathrm{EC}_{50}$ values, mainly in relation to root length parameter $(13.15 \%$ and $22.80 \%$ for $L$. sativa and C. sativus, respectively; Table 6). 
Table 6. Effects of raw and treated effluents on germination and on root length. Median effective concentration $\left(\mathrm{EC}_{50}\right)$ values with their respective confidence intervals are presented in $\% \mathrm{v} / \mathrm{v}$ at Lactuca sativa and Cucumis sativus seed after $120 \mathrm{~h}$ of exposure.

\begin{tabular}{ccc|cc}
\hline & \multicolumn{3}{c}{$\mathbf{E C}_{\mathbf{5 0}} \% \mathbf{v} / \mathbf{v}(\mathbf{C I})$} \\
\hline \multirow{2}{*}{ Effluents } & \multicolumn{2}{c}{ Lactuca sativa } & \multicolumn{2}{c}{ Cucumis sativus } \\
\cline { 2 - 5 } Raw & Seed germination & Root length & Seed germination & Root length \\
\cline { 2 - 5 } & $40.36(35.08-46.44)$ & $13.15(9.91-17.46)$ & $80.62\left(59.10_{-}\right.$ & $22.80\left(17.43_{-}\right.$ \\
Treated & $59.16(49.21-71.09)$ & $67.32(52.78-$ & $110.00)$ & $29.81)$ \\
& & $85.88)$ & $>100$ & $>100$ \\
\hline
\end{tabular}

D'Abrosca ${ }^{43}$ assessed the phytotoxicity of some pharmaceuticals including ethinyl estradiol on several species. The authors observed that $L$. sativa was the most sensitive species for both tested endpoints, inhibiting more than $50 \%$ of seed germination and $25 \%$ of root elongation in the highest tested concentration $\left(10^{-3} \mathrm{~mol} \mathrm{~L}^{-1}\right)$. Our results also showed that $L$. sativa was more sensitive than $C$. sativus. Additionally, we observed a reduction in the toxicity of the raw effluent for both specie tested after the treatment (Fig. 4 and Table 6).

\subsection{Brine shrimp toxicity assay}

Artemia spp. (brine shrimp) presents several advantages, such as a short life cycle and adaptability to wide ranges of salinity, which have contributed to increasing the use of brine shrimps in ecotoxicological studies ${ }^{40,44,45}$. Moreover, ecotoxicity tests with different organisms may be used to determine the effect level of effluents and thus their environmental impacts ${ }^{46}$.

Table 7 shows the percent of mortality (immobility) of A. salina nauplii after $24 \mathrm{~h}$ of exposure to raw and treated effluents. The raw effluent was highly toxic to $A$. salina nauplii with $\mathrm{LC}_{50}-24 \mathrm{~h}$ of $0.58 \%$ whereas the treated samples caused no mortality after $24 \mathrm{~h}$ of exposure (Table 7). Raw effluent induced significant toxicity to $A$. salina nauplii in concentration- and timedependent manners with $\mathrm{LC}_{50}-48 \mathrm{~h}$ of $0.31 \%$ (Table 8). However, the treated effluent also caused significant mortality to $A$. salina in highest tested concentrations (50\% and $100 \%)$ after $48 \mathrm{~h}$ of exposure, which suggests the generation of toxic by-products.

Table 7. Immobilization rate of Artemia salina nauplii after $24 \mathrm{~h}$ of exposure to raw and treated effluents and their median lethal concentrations $\left(\mathrm{LC}_{50}\right)$ causing $50 \%$ of immobilization. NC: negative control; SD: standard deviation of four replicates.

\begin{tabular}{ccccccccc}
\hline $\begin{array}{c}\text { Concentration } \\
(\boldsymbol{\%} \text { v/v })\end{array}$ & \multicolumn{3}{c}{$\begin{array}{c}\text { Number of immobilized } \\
\text { organisms at } \mathbf{2 4} \mathbf{h}\end{array}$} & & Immobilization & $\begin{array}{c}\text { LC } \\
(\boldsymbol{\%} \mathbf{v} / \mathbf{v})\end{array}$ \\
\hline Raw effluent & 1 & 2 & 3 & 4 & SD & Total & $\%$ & 0.58 \\
NC & 0 & 0 & 0 & 0 & 0.0 & $0 / 20$ & 0 & \\
0.01 & 0 & 0 & 1 & 0 & 0.5 & $1 / 20$ & 5 & \\
0.10 & 0 & 0 & 1 & 0 & 0.5 & $1 / 20$ & 5 & \\
1.00 & 5 & 3 & 4 & 2 & 1.3 & $14 / 20$ & $70^{*}$ & \\
5.00 & 4 & 5 & 5 & 4 & 0.6 & $18 / 20$ & $90^{*}$ & \\
10.0 & 5 & 5 & 5 & 5 & 0.0 & $20 / 20$ & $100^{*}$ & \\
\hline Treated effluent & 1 & 2 & 3 & 4 & SD & Total & $\%$ & \\
NC & 0 & 0 & 0 & 0 & 0.0 & $0 / 20$ & 0 & \\
6.25 & 0 & 0 & 0 & 0 & 0.0 & $0 / 20$ & 0 & \\
12.5 & 0 & 0 & 0 & 0 & 0.0 & $0 / 20$ & 0 & \\
25.0 & 0 & 0 & 0 & 0 & 0.0 & $0 / 20$ & 0 & \\
50.0 & 0 & 0 & 0 & 0 & 0.0 & $0 / 20$ & 0 & \\
100.0 & 0 & 0 & 0 & 0 & 0.0 & $0 / 20$ & 0 & \\
\hline
\end{tabular}

"Statistically different $(\mathrm{p}<0.05)$ from the respective negative control $(\mathrm{NC})$. 
Table 8. Immobilization rate of Artemia salina nauplii after $48 \mathrm{~h}$ of exposure to raw and treated effluents and their median lethal concentrations $\left(\mathrm{LC}_{50}\right)$ causing $50 \%$ of immobilization. NC: negative control; SD: standard deviation of four replicates.

\begin{tabular}{|c|c|c|c|c|c|c|c|c|}
\hline $\begin{array}{c}\text { Concentration } \\
(\% \mathrm{v} / \mathrm{v})\end{array}$ & \multicolumn{4}{|c|}{$\begin{array}{l}\text { Number of immobilized } \\
\text { organisms at } 48 \mathrm{~h}\end{array}$} & & \multicolumn{2}{|c|}{ Immobilization } & $\begin{array}{l}\mathbf{L C}_{50} \\
(\% \mathrm{v} / \mathrm{v})\end{array}$ \\
\hline \multirow{2}{*}{$\begin{array}{c}\text { Raw effluent } \\
\text { NC }\end{array}$} & 1 & 2 & 3 & 4 & SD & Total & $\%$ & \multirow[t]{7}{*}{0.31} \\
\hline & 0 & 0 & 0 & 0 & 0.0 & $0 / 20$ & 0 & \\
\hline 0.01 & 0 & 0 & 2 & 0 & 1.0 & $2 / 20$ & 10 & \\
\hline 0.10 & 0 & 2 & 1 & 0 & 0.9 & $3 / 20$ & 15 & \\
\hline 1.00 & 5 & 4 & 5 & 3 & 0.9 & $17 / 20$ & $85^{*}$ & \\
\hline 5.00 & 5 & 5 & 5 & 5 & 0.0 & $20 / 20$ & $100^{*}$ & \\
\hline 10.0 & 5 & 5 & 5 & 5 & 0.0 & $20 / 20$ & $100^{*}$ & \\
\hline \multirow{2}{*}{$\begin{array}{l}\text { Treated effluent } \\
\text { NC }\end{array}$} & 1 & 2 & 3 & 4 & SD & Total & $\%$ & \multirow[t]{7}{*}{53.88} \\
\hline & 0 & 0 & 0 & 0 & 0.0 & $0 / 20$ & 0 & \\
\hline 6.25 & 0 & 0 & 0 & 0 & 0.0 & $0 / 20$ & 0 & \\
\hline 12.5 & 0 & 0 & 1 & 0 & 0.5 & $1 / 20$ & 5 & \\
\hline 25.0 & 0 & 1 & 1 & 0 & 0.6 & $2 / 20$ & 10 & \\
\hline 50.0 & 3 & 1 & 2 & 0 & 1.3 & $6 / 20$ & $30^{*}$ & \\
\hline 100.0 & 5 & 5 & 4 & 5 & 0.5 & $19 / 20$ & $95^{*}$ & \\
\hline
\end{tabular}

Ecotoxicity evaluation with different organisms is useful to determine the toxic effect potential of pharmaceutical effluents and thus their environmental impacts ${ }^{46}$. Additionally, ecotoxicity assays for effluents are mandatory in many countries including Brazil ${ }^{47,48}$. The ecotoxicity test proved that toxicity of the synthetic hormones present in the raw effluent was reduced by electrocoagulation technique herein employed.

\section{Conclusions}

The results obtained allowed to conclude that the electrochemical treatment of the hormonal effluent generated by pharmaceutical industries was efficient in the removal of the compounds studied, in the reduction of organic load, color and turbidity, as well as in the reduction of toxicity to lettuce and cucumber seeds and Artemia salina. Besides that, despite the differences between the used species, A. salina was more sensitive than seeds to detect toxicity. Therefore, the physicochemical analyses carried out in conjunction with bioassays were able to provide valuable information on the quality of synthetic hormones containing effluents, in order to reduce their impact on the environment.

Electrocoagulation may be a promising method in the treatment process of industrial pharmaceutical effluents since it provides electrolytic, physicochemical or electrochemical precipitation of the sludge. Even though it does not entirely remove recalcitrant compounds, electrochemical processes can increase the degree of biodegradability, facilitating degradation by biological processes, reducing their toxicity.

\section{Acknowledgments}

The authors wish to thank Conselho Nacional de Desenvolvimento Científico e Tecnológico (CNPq) [grant number 471109/2013-4] and Financiadora de Estudos e Pesquisas (FINEP) [grant number 01.14.0140.00] for the financial support to this work. Coordenadoria de Aperfeiçoamento de Pessoal (CAPES) for Luane Ferreira Garcia, Emily Kussmaul Gonçalves Moreno and Laís de Brito Rodrigues scholarships. Fundação de Amparo à Pesquisa do Estado de Goiás (FAPEG) and Programa Mobilidade Docente AUGM to assist the participation of events abroad.

\section{References}

[1] Pereira, L. C., de Souza, A. O., Bernardes, M. F. F., A perspective on the potential risks of emerging contaminants to human and environmental health, Environ. Sci. Pollut. Re. Int. $22 \quad$ (2015) 13800-13823. https://doi.org/10.1007/s11356-015-4896-6. 
[2] Archer, E., Petrie, B., Kasprzyk-Hordern, B., Wolfaardt, G. M., The fate of pharmaceuticals and personal care products (PPCPs), endocrine disrupting contaminants (EDCs), metabolites and illicit drugs in a WWTW and environmental waters, Chemosphere 174 (2017) 437-446. https://doi.org/10.1016/j.chemosphere.2017.01.10 1 .

[3] Hilton, M. J., Thomas, K. V., Determination of selected human pharmaceutical compounds in effluent and surface water samples by highperformance liquid chromatography-electrospray tandem mass spectrometry. J. Chromatography A. 1015 (2003)129-141. https://doi.org/10.1016/S0021-9673(03)01213-5.

[4] Hari, A. C., Paruchuri, R. A., Sabatini, D. A., Kibbey, T. C. G., Effects of $\mathrm{pH}$ and Cationic and Nonionic Surfactants on the Adsorption of Pharmaceuticals to a Natural Aquifer Material, Environ. Sci. Technol. 39 (2005) 2592-2598. https://doi.org/10.1021/es048992m.

[5] Santos, L. H. M. L. M., Araújo, A. N., Fachini, A., Ecotoxicological aspects related to the presence of pharmaceuticals in the aquatic environment., J. Hazard. Mater 175 (2010) 45-95. https://doi.org/10.1016/j.jhazmat.2009.10.100.

[6] Xu, J., Xu, Y., Wang, H. Occurrence of antibiotics and antibiotic resistance genes in a sewage treatment plant and its effluent-receiving river, Chemosphere 119 (2015) 1379-1385. https://doi.org/10.1016/j.chemosphere.2014.02.04 0 .

[7] Liu, J-L., Wong, M-H., Pharmaceuticals and personal care products (PPCPs): A review on environmental contamination in China, Environment International, 59 (2013) 208-222. https://doi.org/10.1016/j.envint.2013.06.012.

[8] Yang, Y-Y., Liu, W-R., Liu, Y-S., Suitability of pharmaceuticals and personal care products (PPCPs) and artificial sweeteners (ASs) as wastewater indicators in the Pearl River Delta, South China, Sci. Total Environ. 590-591 (2017) 611-619. https://doi.org/10.1016/j.scitotenv.2017.03.001.

[9] Joseph, E., The dictionary of drugs: chemical data, structures and bibliographies, Springer, 2014.
[10] Liu, Z.-H., Kanjo, Y., Mizutani, S., Urinary excretion rates of natural estrogens and androgens from humans, and their occurrence and fate in the environment: a review, Sci. Total Environ. 407 (2009) 4975-4985. https://doi.org/10.1016/j.scitotenv.2009.06.001.

[11] Kanakaraju, D., Glass, B. D., Oelgemöller, M., Advanced oxidation process-mediated removal of pharmaceuticals from water: a review, J. Environ. Manage. 219 (2018) 189-207. https://doi.org/10.1016/j.jenvman.2018.04.103.

[12] Aquino, S. F., Brandt, E. M. F., Chernicharo, C. A. L., Removal of drugs and endocrine disrupters in sewage treatment plants: literature review, Eng. Sanit. Ambient. 18 (2013) 187-204. https://doi.org/10.1590/S141341522013000300002.

[13] Mirzaei, R., Yunesian, M., Nasseri, S., Occurrence and fate of most prescribed antibiotics in different water environments of Tehran, Iran, Sci. Total Environ. 619-620 (2018) 446-459. https://doi.org/10.1016/j.scitotenv.2017.07.272.

[14] Xiang, J., Wu, M., Lei, J., Fu, C., Gu, J., Xu, G., The fate and risk assessment of psychiatric pharmaceuticals from psychiatric hospital effluent, Ecotox. Environ. Safe. 150 (2019) 289-296. https://doi.org/10.1016/j.ecoenv.2017.12.049.

[15] Xuan, R., Blassengale, A. A., Wang, Q., Degradation of estrogenic hormones in silt loam soil, J. Agric. Food Chem. 56 (2008) 9152-9158. https://doi.org/10.1021/jf8016942.

[16] Tijani, J. O., Fatoba, O. O., Madzivire, G., Petrik, L. F., A review of combined advanced oxidation technologies for the removal of organic pollutants from water, Water Air Soil Pollut. 225 (2014) 2102. https://doi.org/10.1007/s11270-0142012-y.

[17] Ribeiro, A. R., Nunes, O. C., Pereira, M. F. R., Silva, A. M. T., An overview on the advanced oxidation processes applied for the treatment of water pollutants defined in the recently launched Directive 2013/39/EU, Environ. Int. 75 (2015) 3351. https://doi.org/10.1016/j.envint.2014.10.027.

[18] Arvanitoyannis, I. S., Kassaveti, A., Stefanatos, S., Olive oil waste treatment: a 
comparative and critical presentation of methods, advantages \& disadvantages, Crit. Rev. Food Sci. $\begin{array}{llllll}\text { Nutr. } & 47 & \text { (3) (2007) 187-229. }\end{array}$ https://doi.org/10.1080/10408390600695300.

[19] Miklos, D. B., Remy, C., Jekel, M., Linden, K. G., Drewes, J. E., Hübner, U., Evaluation of advanced oxidation processes for water and wastewater treatment - A critical review, Water Research $139 \quad$ (2018) 118-131. https://doi.org/10.1016/j.watres.2018.03.042.

[20] Moreira, F. C., Boaventura, R. A. R., Brillas, E., Vilar, V. J. P., Electrochemical advanced oxidation processes: A review on their application to synthetic and real wastewaters, Applied Catalysis B: Environmental 202 (2017) 217-261. https://doi.org/10.1016/j.apcatb.2016.08.037.

[21] Klavarioti, M., Mantzavinos, D., Kassinos, D., Removal of residual pharmaceuticals from aqueous systems by advanced oxidation processes, Environment International 35 (2009) 402-417. https://doi.org/10.1016/j.envint.2008.07.009.

[22] Sirés, I., Brillas, E., Remediation of water pollution caused by pharmaceutical residues based on electrochemical separation and degradation technologies: a review, Environ. Int 40 (2012) 212229. https://doi.org/10.1016/j.envint.2011.07.012.

[23] Cañizares, P., Jiménez, C., Martínez, F., Saez, C., Rodrigo, M. A., Study of the electrocoagulation process using aluminum and iron electrodes, Ind. Eng. Chem. Res. 46 (2007) 6189-6195. https://doi.org/10.1021/ie070059f.

[24] APHA, AWWA, WEF, Standard Methods for examination of water and wastewater, Washington DC, 22nd ed., 2012.

[25] ChemSpider Search and Share Chemistry, Algestone acetophenide, 2018. Database: http://www.chemspider.com/Chemical-

Structure.4447595.html. Accessed 20 May 2018.

[26] ChemSpider Search and share chemistry, Estradiol enanthate, 2018. Database: http://www.chemspider.com/Chemical-

Structure.19815.html. Accessed 20 May 2018.

[27] USEPA, United States Environmental Protection Agency. Ecological effects test guidelines. $\quad$ OPPTS 850.4200, Seed Germination/Root Elongation Toxicity Test. EPA 712 C (1996) 96-154.

[28] Meyer, B. N., Ferrigni, N. R., Putnam, J. E., Jacobsen, L. B., Nichols, D. E., McLaughlin, J. L., Brine Shrimp: a convenient general bioassay for active plant constituents, Journal of Medicinal Plant Research, 45 (1982) 31-34. https://doi.org/10.1055/s-2007-971236.

[29] Organization For Economic Cooperation And Development [OECD], Guideline for testing of chemicals, Daphnia sp. Acute Immobilization Test, France, Guideline No. 202, 2004.

[30] Crespilho, F. N., Santana, C. G., Rezende, M. O. O., Tratamento de efluente da indústria de processamento de coco utilizando eletroflotação, Quim. Nova, $27 \quad$ (2004) 387-392. https://doi.org/10.1590/S0100-

40422004000300005 .

[31] Benefield, L. D., Judkins, J. F., Weand, B. L., Process Chemistry for Water and Wastewater Treatment, Prentice-Hall, Englewood Cliffs, N.J., 1982.

[32] Cook, M. M., Symonds, E. M., Gerber, B., Hoare, A., Van-Vleet, E. S., Breitbart, M., Removal of Six Estrogenic Endocrine-Disrupting Compounds (EDCs) from Municipal Wastewater Using Aluminum Electrocoagulation, Water 8 (2016) 128. https://doi.org/10.3390/w8040128.

[33] Garcia, L. F., Morais, R. L., Santos, W. T. P., Pacheco, C., Santiago, M. F., Gil, E. S., Low Cost Commercial Anodes on the Electrochemical Remediation of the Estrogen 17a-ethinylestradiol. J. Chem. Pharm. Res. 8 (2016) 958-961.

[34] Pal, A., Gin, KY-H., Lin, AY-C., Reinhard, M., Impacts of emerging organic contaminants on freshwater resources: review of recent occurrences, sources, fate and effects, Sci. Total Environ. 408 (2010) 6062-6069. https://doi.org/10.1016/j.scitotenv.2010.09.026.

[35] Kerr, J. L., Guo, Z., Smith, D. W., Goss, G. G., Belosevic, M. (2008) Use of goldfish to monitor wastewater and reuse water for xenobiotics, J. Environ. Eng. Sci. 7 (4) (2008) 369383. https://doi.org/10.1139/S08-011. 
[36] Leusch, F. D. L., Khan, S. J., Gagnon, M. M., Quayle, P., Trinh, T., Coleman, H., Rawson, C., Chapman, H. F., Blair, P., Nice, H., Reitsema, T., Assessment of wastewater and recycled water quality: a comparison of lines of evidence from in vitro, in vivo and chemical analyses, Water Res. 50 (2014) 420-431. https://doi.org/10.1016/j.watres.2013.10.056.

[37] Klauck, C. R., Giacobbo, A., Oliveira, E. D. L., Silva, L. B., Rodrigues, M. A. S., Evaluation of acute toxicity, cytotoxicity and genotoxicity of landfill leachate treated by biological lagoon and advanced oxidation processes, J. Environ. Chemic. Eng. 5 (2017) 6188-6193. https://doi.org/10.1016/j.jece.2017.11.058.

[38] Zhang, W., Liu, W., Zhang, J., Zhao, H., Zhang, Y., Quan, X., Jin, Y., Characterization of acute toxicity, genotoxicity and oxidative stress posed by textile effluent on zebrafish, J. Environ. Sci. 24 (2012) 2019-2027.

[39] Boutin, C., Strandberg, B., Carpenter, D., Mathiassen, S. K., Thomas, P. J., Herbicide impact on non-target plant reproduction: what are the toxicological and ecological implications? Environ. Pollut. 185 (2014) 295-306. https://doi.org/10.1016/j.envpol.2013.10.009.

[40] Oliveira, G. A. R., Leme, D. M., de Lapuente, J., Brito, L. B., Porredón, C., Rodrigues, L. B., Brull, N., Serret, J. T., Borràs, M., Disner, G. R., Cestari, M. M., Oliveira, D. P., A test battery for assessing the ecotoxic effects of textile dyes, Chem Biol Interact., 291 (2018) 171-179. https://doi.org/10.1016/j.cbi.2018.06.026.

[41] Wang, X., Sun, C., Gao, S., Wang, L., Shuokui, H., Validation of germination rate and root elongation as indicator to assess phytotoxicity with Cucumis sativus. Chemosphere 44 (2001) 1711-1721. https://doi.org/10.1016/s00456535(00)00520-8.

[42] Lyu, J., Park, J., Pandey, L. K., Choi, S., Lee, H., De Saeger, J., Depuydt, S., Han, T., Testing the toxicity of metals, phenol, effluents, and receiving waters by root elongation in Lactuca sativa L., Ecotoxicol. Environ. Saf. 149 (2018) 225-232. https://doi.org/10.1016/j.ecoenv.2017.11.006

[43] D'Abrosca, B., Fiorentino, A., Izzo, A.,
Cefarelli, G., Pascarella, M. T., Uzzo, P., Monaco, P., Phytotoxicity evaluation of five pharmaceutical pollutants detected in surface water on germination and growth of cultivated and spontaneous plants, J. Environ. Sci. Health A, 43 (2008) 285-294. https://doi.org/10.1080/10934520701792803.

[44] Nunes, B. S., Carvalho, F. D., Guilhermino, L. M., Stappen, G. B., Use of the genus Artemia in ecotoxicity testing, Environ. Pollut. 144 (2006) 453-462.

https://doi.org/10.1016/j.envpol.2005.12.037.

[45] Libralato, G., Prato, E., Migliore, L., Cicero, A. M., Manfra, L., A review of toxicity testing protocols and endpoints with Artemia spp, Ecol. Indicat. $\quad 69 \quad$ (2016) 35-49. https://doi.org/10.1016/j.ecolind.2016.04.017.

[46] Maselli, B. de S., Luna, L. A. V., Palmeira, J. de O., Tavares, K. P., Barbosa, S., Beijo, L. A., Umbuzeiro, G. A., Kummrow, F., Ecotoxicity of raw and treated effluents generated by a veterinary pharmaceutical company: a comparison of the sensitivities of different standardized tests, Ecotoxicology $24 \quad$ (2015) 795-804. https://doi.org/10.1007/s10646-015-1425-9.

[47] Pessala, P., Schultz, E., Nakari, T., Joutti, A., Herve. S., Evaluation of wastewater effluents by small-scale biotests and a fractionation procedure, Ecotoxicol. Environ. Saf. 59 (2004) 263-272. https://doi.org/10.1016/j.ecoenv.2003.10.002.

[48] CONAMA, Conselho Nacional do Meio ambiente, Resolucão CONAMA no 430, de 13 de maio de 2011. 